\title{
Exploring the Myths about Online Education in Information Systems
}

\author{
Suprateek Sarker and Jennifer Nicholson \\ Washington State University \\ Pullman, WA, USA
}

sarkers@cbe.wsu.edu jnicholson@wsu.edu

\begin{abstract}
Rapid proliferation of the Internet along with emerging social and economic imperatives are leading institutions of higher-learning to offer a large variety of online courses/programs in different disciplines. As such education becomes increasingly pervasive and legitimate in society, there is a need to critically examine its merits and pitfalls as well as the underlying assumptions driving the justification, design, and teaching of online courses. In this paper, we take a first step in this direction by uncovering myths embedded in the discourse on online learning. We examine these myths in the context of online education in our own discipline, that of Information Systems (IS). We intend the paper to stimulate awareness and encourage debate regarding the pedagogical, administrative, economic, and societal implications of this novel though untested form of education as practiced in IS as well as in related disciplines.
\end{abstract}

\section{Introduction}

The proliferation of the Internet has spawned an increased offering of online courses by many educational institutions. This pattern is quite noticeable among many Business Schools in the United States, which are increasingly leaning toward offering online programs, especially in the area of Information Systems (IS) where courses have been in very high demand (Piccoli, Ahmad, \& Ives, 2001). What is still unknown, however, is whether courses offered in this domain can measure up to the traditional information systems education one can receive by attending a "brick and mortar" institution, and how online education can be made as effective as possible.

There are two distinctly opposing beliefs regarding these issues. To some, computers and related technologies signal greater control and may even be seen as possessing magical qualities (KaarstBrown \& Robey, 1999) that could serve as a panacea for what ails education. For others, however, the enabling Information Technology (IT) still remains part of the unknown (Kaarst-Brown \& Robey, 1999) and, therefore, technological mediation of the fundamental socialization process of education, especially when such education pertains to information technology and its applica-

Material published as part of this journal, either online or in print, is copyrighted by the publisher of Informing Science. Permission to make digital or paper copy of part or all of these works for personal or classroom use is granted without fee provided that the copies are not made or distributed for profit or commercial advantage AND that copies 1 ) bear this notice in full and 2) give the full citation on the first page. It is permissible to abstract these works so long as credit is given. To copy in all other cases or to republish or to post on a server or to redistribute to lists requires specific permission and payment of a fee. Contact Editor@inform.nu to request redistribution permission. tions, warrants careful investigation (Rudestam \& Schoenholtz-Read, 2002). The uneasiness felt by those adopting the latter viewpoint is reflected in the words of an online instructor for IS courses who stated, "We have the awkward position of teaching technology through technology." We feel that the time is ripe to critically examine the merits and underlying assumptions driving the justi- 
fication, design, and delivery of such courses, and, as a community, to reflect on the pedagogical, administrative, economic, and societal implications of online IS education.

In particular, we discern seven myths from the literature on online education. We are not aware of any previous effort by academic scholars to infer and articulate myths regarding on-line educa-

tion. While we do not claim that the seven myths offered are comprehensive in scope, we feel that they do provide a good starting point to critically understand this emergent form of education. We examine these seven myths in a context consisting of a reasonably varied set of IS courses, instructors, and students in a US university, with a solid reputation as a brick and mortar institution, making its forays into the realm of web-based distance degree programs.

\section{The State of Online Education in General}

According to the PBS website (http://www.pbs.org/als/dlweek/history/index.html), distance learning "has been around since the advent of the written language." The "modern history" of distance education can be traced to the 1800's, when it was referred to as "correspondence study" with study material and assignments being transferred through the postal service. The successful introduction of audiovisual technologies in the early 1900s "generated a renewed interest" in distance education (Reiser, 1987), and with the advent of the Internet, distance education enabled by web-based technologies has become enormously popular, both among providers and consumers of education (Aggarwal \& Bento, 2000; Belanger \& Jordan, 2000). Given the vast scope of distance education, and recognizing the current technological trends associated with this form of education, we wish to focus the discussion in this paper to internet-based distance education, also referred to as online education. For the purpose of this paper, we define online education as coursework delivered to students who are geographically separated from the instructor(s) and who use information and communication technologies (ICTs), particularly the Internet, for interactions (Rudestam \& Schoenholtz-Read 2002).

Reports from IDC research and Bersin and Associates estimate that worldwide spending on online continuing education exceeded the 9 billion US Dollar mark in 2003 and grew to between $\$ 12$ and 14 billion US Dollars in 2004. Furthermore, IDC predicts a 30\% increase in annual elearning spending worldwide through 2008 (http://accounting.smartpros.com/x46477.xml). Peter Drucker, business guru and futurist, caused quite a stir in the academic community when, in an interview for Forbes magazine, he stated that universities thirty years from now would be "relics ... [and] won't survive" (Lenzer \& Johnson, 1997, p. 127). Money Magazine has said, "Online education may be the greatest technological advance to hit academia since the No. 2 pencil" (Clarke, 1998, p. 66), and John Chambers, the chief executive officer of Cisco Systems, has declared that "e-learning is the next major killer app" of the Internet (Moore, 2001; "The Virtual Classroom,” 2000). In fact, it has become such big business, that major investors, such as Michael Milken's Knowledge Universe and Paul Allen's click2learn.com, are jumping on the bandwagon to offer courses to both college students and corporate trainees (Molenda \& Harris, 2001). Media financier, Herbert Allen, Jr. is the primary promoter of Global Education Network (GEN), a consortium of top-notch liberal arts colleges and ivy-league universities, including Brown, Wellesley and Williams, brought together to provide online education ("The Virtual Classroom," 2000; Weber, 2000). Additionally, some universities, such as University of Maryland and Columbia University, are forming their own for-profit subsidiaries to offer online degree programs in order to exploit their "intellectual capital," presumably without diluting the reputation of their brick-andmortar university (Molenda \& Harris, 2001). Thus, it is evident that higher education institutions, including those with outstanding "brick-and-mortar" historical reputations, as well as major investors, are charging ahead in an effort to capture a share of the online education market. But what are the driving forces behind this trend toward online education? Below, we briefly discuss some of reasons that are cited in the literature. 
Adult students, those 25 years of age and over, currently represent nearly one-half of credit students enrolled in higher education (Kasworm, Sandmann, \& Sissel, 2000), yet they have greater work and family responsibilities that prevent them from attending school full time. These students, then, may be choosing an online course because of lifestyle issues. Another driving force is the increasing cost of education and the lack of financial aid available for those students who would like to attend full time (Raymond, 2000). Thus, students may be forced to choose an online course for financial reasons. The pervasiveness of information technology into the workplace has also created a growing societal demand for continuing education, requiring many workers to acquire new skills (Molenda \& Harris, 2001). In this day and age, most large companies are sold on the idea that continual training and retraining of employees will yield large returns ("The Virtual Classroom,” 2000). In addition, technology in and of itself is a major driving force. As more and more people have access to a computer and the Internet, it is easy to fall into a mindset of thinking "since it's there, we should use it." Finally, as government support for public institutions is shrinking, nonprofit institutions are being forced to find their niche in the marketplace and operate more like a for-profit business. Many of these institutions are turning to online education as a way to support themselves within the marketplace (Molenda \& Harris, 2000). As such, for-profit and non-profit institutions are competing for the upper hand in the headlong rush to implement new technology. Herbert Allen, Jr.'s for-profit venture, GEN, has its own conception of the driving force behind this trend and is targeting four distinct markets with its online courses: 1) "lifelong learners" who graduated from college decades ago but want to challenge themselves; 2) college students at smaller institutions who want to supplement their studies with courses not offered on their real-life campuses; 3) high-school students gearing up for competitive college-admission processes; and 4) students overseas who want access to U.S. educational institutions (Weber, 2000).

While online education is being touted aggressively, there are some opposing voices. However, these voices are muted by the sheer weight of technological and economic determinism, the basis for much of the uncritical optimism regarding online teaching and learning. Among those voices are 840 faculty members from the University of Washington (UW) who signed an open letter objecting to Washington State's Governor Gary Locke's 1998 proposal of a distance-learning initiative that suggested traditional state-university courses could be partly replaced by online learning (Cleary, 2001). These opposing faculty argued that education should not be reduced to "the downloading of information, much less to the passive and solitary activity of staring at a screen" (Cleary, 2001). It is worth noting that the UW professors are not alone in their skepticism of online education. When Peter Lange, the Provost of Duke University, was approached by GEN, he was impressed by what GEN had to offer. Yet, he expressed his reservation regarding the extent to which online education can be universally effective, and suggested that online learning be approached on a course-by-course basis. "Can a company like GEN put together a full curriculum which would substitute for what you would get if you came to Duke? The answer is clearly no," he says (Weber, 2000). William S. Reed, the vice president for finance and administration at Wellesley, declared that he is not sure if Wellesley's courses can be successfully translated into Web pages (Weber, 2000), yet Wellesley has agreed in principle to join the GEN venture. Even U.K.'s Open University, an institute that creates and studies ways of applying new technologies to learning, has some harsh words regarding online education. "For online education to become mainstream is kind of a depressing thought, because it is such a crappy experience. The bottom line is that learning online is a soul-destroying experience. It really, really stinks. It's always second best (to face-to-face learning)," said Marc Eisenstadt, chief scientist for the Knowledge Media Institute at the U.K.'s Open University (Hamilton, 2001). Moreover, the jury is still out on the issue of online education at organizations such as the AACSB, the primary accrediting organization for business schools in the United States, which typically house Information Systems departments as well. While the AACSB "encourages innovation and experimentation in education” 
in its guidelines, they also caution "simply adopting new technologies without thinking about the implications for quality assurance would raise troubling questions” (Cleary, 2001). The sentiments of those who are erring on the cautious side before jumping feet first into online education can be properly summed up by Arthur Levine, president of Teachers College at Columbia University in New York, when he said, "We still don't know if online education is any good" (Cleary, 2001).

Regardless of which side of the fence in this click versus brick divide you are on, or maybe you are straddling the fence, one thing is clear -- the debate that surrounds this form of education is not one that is likely to be resolved any time soon. As IS educators who believe in the importance of imparting knowledge pertaining to technical aspects as well as managerial/business aspects, our own position in this debate is one of cautious optimism - while we see significant gains that can be derived from online education, we consider the taken-for-grantedness of the presumed merits, largely fuelled by financial and technical opportunism, as being potentially detrimental to the long-term disciplinary and societal interest of developing reflective IS practitioners.

\section{What do We Know About Online IS Education?}

Few would contest the characterization that the IS literature on on-line education is in its infancy. Nevertheless, IS scholars have made a number of important contributions to the knowledge in this area, focusing on the enabling technology, the motivations behind the trend toward increased elearning, implementation guidelines, and the differences between various facets of face-to-face versus on-line education. Much of the literature is comprised of articles with theoretical analysis or opinion pieces. For example, Morrissey (2002) and Huhn, Umesh, and Valacich (2003) discuss the business aspect of e-learning, including who is offering it and how to effectively implement internet-based courses. Dufner, Kwon, and Hadidi (1999) and Zhang and Nunamker (2003) discuss the technologies that enable e-learning. Neumann (1998) and Schank (2001) discuss issues involved in developing and delivering online courses, such as the types of courses best suited for the online environment, the amount of prep that goes into teaching an online course, and potential loss of interactions. Coppola, Hiltz, and Rotter (2002) discuss the changing roles of faculty members while Hiltz and Turoff (2002) stress the importance of interactivity in making the learning experience as effective as possible.

There have also been a few empirical studies using quantitative analysis conducted as well. Picoli, Ahmad, and Ives (2001) developed a framework for Virtual Learning Environment (VLE) effectiveness and investigated learner control in a web-based VLE versus a traditional classroom. No significant differences were found between the two environments. $\mathrm{Lu}, \mathrm{Yu}$, and Liu (2003) examined individual characteristics of students on their learning performance and found no significant impact. Abraham (2002) utilized techniques for an active learning environment in a virtual MIS classroom and found no significant difference between the virtual classroom and the traditional classroom. Benbunan-Fich and Hiltz (2003) compared the process and outcomes of courses being delivered totally online, traditional courses, and courses with a mix of traditional and online activities and found no significant difference in perceived learning between the three modes of delivery. They did, however, hypothesize several mediators that had a significant effect on perceived learning for online courses. A brief overview of the literature in this area is presented in Table 1. 
Table 1: Overview of IS Literature on Online Education

\begin{tabular}{|c|c|}
\hline Citation & Summary \\
\hline Aggarwal (2003) & $\begin{array}{l}\text { Discusses the importance of keeping employees’ IT skills up to } \\
\text { date, with web-based training being one option. }\end{array}$ \\
\hline Benbunan-Fich and Hiltz (2003) & $\begin{array}{l}\text { Compare the process and outcomes of courses delivered totally } \\
\text { online, traditional face-to-face courses, and courses using a mix of } \\
\text { traditional and online activities. While there was no significant dif- } \\
\text { ference in perceived learning across the different modes of delivery, } \\
\text { several mediators were hypothesized that affected perceived learn- } \\
\text { ing in an online course. }\end{array}$ \\
\hline Huynh, Umesh, and Valacich (2003) & $\begin{array}{l}\text { Identify four major models of e-learning businesses that have } \\
\text { emerged over the past five years and examine the competitive } \\
\text { strengths, target markets, advantages, and challenges of each. }\end{array}$ \\
\hline Lu, Yu, and Liu (2003) & $\begin{array}{l}\text { Identify the impact of student learning styles, learning patterns, and } \\
\text { other selected factors on their learning performance in an online } \\
\text { MIS graduate course. With the exception of ethnic group, none of } \\
\text { the factors were found to significantly impact a students' learning } \\
\text { performance. }\end{array}$ \\
\hline Zhang and Nunamaker (2003) & $\begin{array}{l}\text { Discuss the demands for e-Learning and related research as well as } \\
\text { the various technologies that can facilitate the design and imple- } \\
\text { mentation of e-Learning systems. }\end{array}$ \\
\hline Abraham (2002) & $\begin{array}{l}\text { Identifies techniques for an active learning environment in a virtual } \\
\text { MIS classroom and compare outcomes from a distance learning } \\
\text { MIS course with a regular, live, MIS course. No significant differ- } \\
\text { ences were found. }\end{array}$ \\
\hline Coppola, Hiltz, and Rotter (2002) & $\begin{array}{l}\text { Present a qualitative study of role changes that occur when faculty } \\
\text { become online professors. }\end{array}$ \\
\hline Hiltz and Turoff (2002) & $\begin{array}{l}\text { Summarize what is known about making learning networks effec- } \\
\text { tive as a means of course delivery as well as recommend the three } \\
\text { most important factors for effectiveness, all designed to maximize } \\
\text { interactivity. }\end{array}$ \\
\hline Morrissey (2002) & $\begin{array}{l}\text { Explores a new phase of development in the virtual university } \\
\text { movement that is characterized by inter-university coalitions that } \\
\text { share information and communication technology platforms to de- } \\
\text { velop and deliver web-based courses. }\end{array}$ \\
\hline Piccoli, Ahmad, and Ives (2001) & $\begin{array}{l}\text { Discuss the concept of virtual learning environments (VLE), present } \\
\text { a framework of VLE effectiveness, and compare learner control, a } \\
\text { VLE design variable, in a web-based VLE to a traditional class- } \\
\text { room. No significant differences in performance were found. }\end{array}$ \\
\hline Schank (2001) & $\begin{array}{l}\text { Discusses issues in developing online courses. Advocates teaching } \\
\text { courses online that are centered on learning by doing (e.g. pro- } \\
\text { gramming). }\end{array}$ \\
\hline Yellen (2000) & $\begin{array}{l}\text { Discusses distance education as a way to train future IS workers and } \\
\text { offers solutions to the following problems that accompany distance } \\
\text { education: perceived or actual difficulty using the technology, pas- } \\
\text { sive nature of online training, and trainee motivation. }\end{array}$ \\
\hline Dufner, Kwon, and Hadidi (1999) & $\begin{array}{l}\text { Describes the underlying concepts, architecture, and design of } \\
\text { WebCT for geographically distributed IS students and working pro- } \\
\text { fessionals. }\end{array}$ \\
\hline Neumann (1998) & $\begin{array}{l}\text { Discusses some of the disadvantages that accompany online educa- } \\
\text { tion, such as the amount of prep required to build and teach a } \\
\text { course, conflict over ownership of the material, loss of interactions. }\end{array}$ \\
\hline
\end{tabular}


Three notable points emerged as we examined the literature discussed above. First, few of the articles actually focused on the on-line education as it pertains to Information Systems discipline. Second, most studies adopted a taken-for-granted perspective on on-line education phenomenon as well as on the principles of education implicit in the discourse fuelling the trend, focusing on instrumental issues such as technology use and the modalities of delivery. Finally, the authors on this topic in the IS literature rarely incorporated the subjects' own experiences and understanding explicitly as a basis for developing their theoretical understanding, as evident in formal propositions stated and tested. Given the above observations, and in light of the hype that has accompanied this new form of learning, and the significant investment of both money and time that has gone into creating online educational ventures, we believe that there needs to be a careful examination of the assumptions underlying the discourse on this topic, with the goal of separating hype as well as the results of armchair theorizing from reality. In this paper, we attempt such an examination in the context of IS courses. Following the approach of Davenport and Stoddard (1994), we explore some of the recurring myths on the topic of online education, in the context of IS courses, and from the point of view of online course participants (i.e., both instructors and students), so as to ensure adequate consideration of the "subjective understanding" as the IS academic community proceeds to develop a credible "interpretive understanding” or a valid "positivist understanding” (Lee, 1991).

The specific myths examined in this paper are listed below:

MYTH \#1: Technological connectivity implies interaction among participants in online IS courses.

MYTH \#2: For online IS courses to be effective, they should embody a studentcentered learning philosophy.

MYTH \#3: Online IS course instructors need to enact a "Guide on the Side" mentality rather than being a "Sage on the Stage."

MYTH \#4: Any IS faculty can teach online, any IS student can learn online, and any IS course can be taught online.

MYTH \#5: IS Faculty-members receive the same support and rewards for teaching an online course as they do for teaching a traditional course.

MYTH \#6: Online IS courses provide Just-in-time (JIT) learning.

MYTH \#7: Universities rushing to offer online courses in IS are seen as "digital diploma mills."

\section{Myths - Symbolisms that Reflect a Community's Unspoken Assumptions, Beliefs, and Theories of Action}

Symbols embody a community's views (or theories) about particular phenomena, which in turn explain behaviors exhibited by members of the community. Thus, symbolisms, particularly myths, can be used to make sense of situations that are new, problematic, ambiguous, or unsettled (Frost \& Morgan, 1983). Symbolism revolves around shared meanings - patterns of beliefs, rituals and myths, which evolve through time and function as social glue, binding communities together (Smircich, 1983). In the realm of online education, where there exists, for many, an absence of experience to guide practice, the images and ideas embedded in the discourse reflect and simultaneously shape people's views (Schultze \& Orlikowski, 2001) towards this new form of education. 
Unlike mainstream positivist research studies, which are concerned with the empirical testability of theories in an attempt to increase their predictive power regarding a phenomenon, our paper is built on an interpretivist foundation, as we are attempting to understand phenomena through accessing the meanings that participants assign to them (Orlikowski \& Baroudi, 1991). The interpretive perspective emphasizes the importance of the social-political context, subjective meanings, and symbolic actions in the processes through which humans construct and reconstruct reality (Morgan, 1983, p. 396). Within interpretivism, the language humans use to describe social practices are believed to actually constitute those practices (Orlikowski \& Baroudi, 1991). Adopting the interpretive perspective, we contend that an examination of embedded symbolisms, such as myths in the language of writers/speakers on online education, will enable an understanding of the common attitudes and beliefs surrounding online education. Such an approach can contribute to a holistic and deeper comprehension of the "socially constructed" reality regarding this phenomenon.

Myth can be defined as a "dramatic narrative of imagined events, usually used to explain origins or transformations of something. [It also reflects] an unquestioned belief about the practical benefits of certain techniques and behaviors that is not supported by demonstrated facts" (Trice \& Beyer, 1984, p. 655). Myths are often communicated through the telling of a story. Nonetheless, they are not mere narratives of any particular tale, but actually provide ways of classifying and organizing reality (Polkinghorne, 1988, p. 83). Myths are devices of mind that have been used throughout time to provide explanations, reconcile contradictions, and help resolve dilemmas; however, myths have also been known to distort images and misdirect attention (Bolman \& Deal, 1984). Negative traits notwithstanding, "myths are necessary to create meaning, solidarity and certainty" (Bolman \& Deal, 1984) and serve the following functions: 1) myths explain, 2) myths express, 3) myths maintain solidarity and cohesion, 4) myths legitimize, 5) myths communicate unconscious wishes and conflicts, 6) myths mediate contradictions, and 7) myths provide narrative to anchor the present to the past (Cohen, 1969). An example of this is the "myth of academe," which represents the belief that faculty lead lives devoted to the selfless pursuit of knowledge in institutions carefully organized to support that pursuit (Shaw, 2000).

In the field of IS, noted authors have explored myths related to phenomena that have been of immediate interest to the academic and practitioner communities. For example, Davenport and Stoddard (1994) discuss a number of reengineering-related myths that they describe as "powerful tools for the evangelism." Examples of such myths include "The Myth of Reengineering's Novelty," "The Myth of the Clean Slate," "The Myth of IS Leadership," and "The Myth of TopDown Design,” which Davenport and Stoddard concluded to be "fundamentally false.” Similarly, Hirschheim and Newman (1991) have critically scrutinized myths related to Information Systems Development (ISD) such as "Resistance to ISD is dysfunctional and should be eradicated," "IS should be integrated wherever possible," and "The systems developer is generally the best person to make decisions about a system.”

It is important to note here that a myth is not necessarily false or empirically invalid. Rather, it is a belief that is assumed to be valid even in the presence of contrary evidence or in the absence of any evidence at all (Hirschheim \& Newman, 1991). Given that theories of action guiding practice are embedded in myths, it is essential that they be carefully examined and discredited/rejected if they are repeatedly found to be incompatible with empirical observations (Argyris \& Schon, 1978; Sarker \& Lee, 2002). In the following sections, we describe how we discerned the myths on the topic of online learning, and thereafter, examined them in the context of an on-line undergraduate program in IS offered by a large state university in the US. 


\section{Methodology}

The following steps outline how we went about unearthing the myths embedded within the literature on online education. The first step in discovering the seven myths involved the selection of articles for analysis. We used Pro-Quest Direct and ERIC to search for peer-reviewed articles that contained at least one of the following terms: online learning, online courses, online education, online instruction, web-based instruction, web-based courses, Internet courses, e-learning, computer-based instruction. Published research articles were used as the unit of analysis as they "provide a clear sampling frame, as well as the best view of what is accepted in the research community” (Watson-Manheim, Crowston, \& Chudoba, 2002). Although the articles selected for analysis ranged in publication date from 1996-2002, a majority of the articles (14 out of the 21 that were chosen) were published between 2000 and 2002, as this seems to be the period of time during which online education emerged as a "hot" topic. A total of twenty-one articles were chosen for review based on the fact that they contained recommendations for how to design and teach an online course, offered "lessons learned" from real-life experience in teaching an online course, or presented issues to consider when teaching an online course.

The second step in our analysis was to examine each article in search of common myths embedded in the discourse on online education. After making a comprehensive list of the myths found in these works, they were sorted in order to determine which myths were most prominent throughout these articles.

Finally, using techniques such as semi-structured interviews, we captured the points of view of 5 key faculty members involved in designing and teaching a variety of online courses, including Introduction to MIS, COBOL Programming, Visual Basic Programming, and Database Systems, at a large US University. We also utilized the detailed reflection documents of several students enrolled in these online courses, wherein students wrote about various facets of their experiences in the courses. Sampling strategy was opportunistic, and we acknowledge that the sample size was limited; we make no formal claim of generalizability in this exploratory paper. However, we believe that our evidence/interpretation of evidence is still valuable, in that it does point to some interesting elements related to beliefs and experiences regarding online education that are worthy of consideration by the online educational community. Once a better understanding of the participants' views have been obtained using such exploratory studies, as a next step, a more formal and generalizable validation of the "myths" by surveying a large and diverse sample of on-line IS education stakeholders can be pursued.

\section{Discussion}

In this section, we discuss specific myths that pertain to issues of direct relevance to our IS academic community and present the IS course participants' views on issues addressed by the myths.

\section{MYTH \#1: Technological connectivity implies interaction among participants in online IS courses.}

Interaction is a key component in any learning experience (Dewey, 1938; Vygotsky, 1978), and this has become one of the most pervasive constructs in distance education. In fact, there exists the belief that online education provides an element of interaction that is absent in the traditional classroom (Rudestam \& Schoenholtz-Read, 2002). This interaction is created via bulletin boards, e-mail and chat rooms (Abraham, 2002).

It has been suggested that unlike a traditional university, where students have difficulty finding time to meet with and to learn from one another, online education offers students the opportunity to interact whenever they have time (Shedletsky \& Aitken, 2001). The technology used to deliver 
online education is also said to promote interaction through its ability to enable synchronous as well as asynchronous communication (Hiltz, 1995; Schrum, 1999) rendering face-to-face communication unnecessary (Liaw \& Huang, 2000). The interactive component of technology is also believed to eliminate the time and space barriers between instructors and their physically distant students, thus recreating the classroom environment and allowing learners to engage in learning at their convenience with respect to place and time (Bernard, Rojo de Rubalcava, \& St.Pierre, 2000). The online environment is said to overcome isolation (Bernard et al., 2000; Eastmond, 1996), promote serendipitous encounters (Eastmond, 1996), and provide valuable intellectual exchanges profitable to all (Carr-Chellman \& Duchastel, 2001). A further benefit of technology that appears in the literature is that the student can receive individual and immediate feedback and reinforcement from both instructors and peers (Raymond, 2000).

\section{Preliminary analysis based on evidence}

Some of the students and instructors participating in our study did have views consistent with the literature. For example, a student remarked, "In an online environment you are forced to interact with your classmates in order to learn. In a traditional classroom, you can attend the class and then read the book and learn what it is you are required to learn." Similarly, an instructor indicated "I have better interaction with my online classes than I do with my [FTF] classes... Sometimes people are more inclined to share what they are thinking over e-mail.”

In contrast, one student indicated that while she felt she could interact in the online environment if necessary, she did not find it "as enabling" as a [traditional FTF] class that she had attended. Notably, an overwhelming number of students and instructors emphasized that the online environment does not directly lead to greater interaction, though it did create "potential for interaction" in many circumstances. For example, a student wrote the following in his reflection report: “...the online educational forum 'can' provide an element of interaction that is missing in traditional classroom setting. I emphasize 'can' simply because the avenue of opportunity is present in most of the online forums, it is often a utility that is NOT always utilized." A similar view was presented by an instructor, who said, "I think it gives students the opportunity to interact more, but just because the connectivity is there does not mean that they are going to do it... I... have lots of students that do not really participate."

In summary, we feel that there is a need to be very cautious of the technocentric view suggesting that technological connectivity automatically leads to greater interactions (and thus greater satisfaction and effectiveness in learning). Instead, consistent with the sociotechnical perspective, we believe, as suggested by a significant proportion of the respondents, that ICTs can act as potential enablers of productive and satisfying interactions, but such interactions depend on the participants behavior and can only "emerge" when the appropriate social enablers and interventions (e.g., teaching styles, norms, responsiveness and enthusiasm of the instructors) "fit" with the technological platform for the courses (Markus \& Robey, 1988; Piccoli, Ahmad, and Ives, 2001).

\section{MYTH \#2: For online IS courses to be effective, they should em- body a student-centered learning philosophy.}

Distance education researchers portray the traditional classroom setting as being based on a teacher-centered and a passive-student model. The image of classroom instruction promoted by distance education proponents is one of a boring lecturer who drones on, while students sit idly trying to absorb enough information so that they can regurgitate it for a test and forget it (Markel, 1999). Online education, on the other hand, is declared to be "a more student-centered, collaborative, and egalitarian learning environment” (Weisenberg \& Hutton, 1996). In this new paradigm, students become self-motivated managers of their own learning instead of passive bystanders, with the ability to select learning activities that best fit their backgrounds, interests, and careers 
(Zhang and Nunamaker, 2003), while instructors move away from the roles of an oracle, lecturer, and purveyor of knowledge toward those of a facilitator, guide, and mentor (Bernard et al., 2000; Eastmond, 1996; Leidner \& Jarvenpaa, 1995; Murphy \& Cifuentes, 2001; Raymond, 2000; Shedletsky \& Aitken, 2001; Weisenberg \& Hutton, 1996). In essence, it is believed that the online forum breaks down the teacher-student hierarchy (Weisenberg \& Hutton, 1996).

\section{Preliminary analysis based on evidence}

Interestingly, students, in general, appeared to agree with the point of view that online courses needed to be student-centered in order to be effective, though the notion of "student-centered" had very different meanings for different students. For example, a student stated that, "For the most part, online learning environments would NOT work as well as they do (or can), if it wasn't centered around time-frames and general interests of students taking the online courses.” Another stated that "Online learning... forces the student to do a lot of learning on his or her own. [All of] this... contributes to the student-centered environment." Yet another student felt that "online classes are more student-centered because they are self-driven.” Thus, student-centeredness was conceptualized as being focused around students' times and interests, self-learning undertaken by students, and courses being "self-driven," which are not congruent with the definition-in-use of student-centered education in the literature. An interesting point worth mentioning is that participants did not see student-centered courses as breaking down the "student-teacher hierarchy." This is evident from statements such as "You still usually have to agree with the instructor when opinions are asked or the grade suffers."

The views of instructors varied across the board, some rejecting the concept of student-centered learning, some viewing it with suspicion, and others expressing full agreement. Examples of quotations suggesting rejection include "[The educational research community] believes in the inherent goodness of students and that they are totally motivated... there is an egalitarianism that says student and teacher are on the same level. I don't see that, I see... a discipleship in imparting," or "It is equivalent to saying my family is 'child-centered'... It doesn't make sense.” One of the instructors stated, "If I was lazy building my online course... It takes a lot less work to make a student-centered online course," indicating his suspicion regarding the idea of student-centered teaching. Another instructor, however, indicated general agreement with the idea underlying the myth. He stated, "My role becomes more of a mentor or a pointer to resources, and an explainer of those things they [students] don't get. It is more student-centric, absolutely, because you are answering questions the students have because they couldn't figure out...”

Our conclusion after reviewing the various points of view on this issue is that the notion of student-centeredness needs to be further clarified before one can even start determining whether or not the student-centered philosophy is a precondition for effective online IS courses.

\section{MYTH \#3: Online IS course instructors need to enact a "Guide on the Side" mentality rather than a being a "Sage on the Stage."}

This myth, somewhat related to myth \#2, arises from and also reinforces the belief regarding the (allegedly) changing role of faculty. The word "sage” refers to an experienced or profoundly wise person, whereas a "guide" is someone who assists, facilitates, or supervises. Thus, in a traditional education setting, the instructor is referred to as a sage and the classroom serves as his stage. However, in the online domain, the instructor acts as more of a guide, assisting students in knowledge construction from the sidelines rather than projecting knowledge from center stage. It has been said that "a transition is occurring from 'teaching by telling' to 'learning-on-demand' or 'learning by asking or doing'” (Zhang and Nunamaker, 2003). This myth therefore implies that 
online education either automatically enables a change, or at the very least, requires a change in attitude/approach of the instructor in order to be effective (Coppola, Hiltz, \& Rotter, 2002). In fact, Rudestam and Shoenholtz-Read (2002) claim that such a shift in pedagogical approach (from an authoritative/directive approach to a facilitative/participative approach) in an Internetenabled educational environment is a necessity, and refer to this claim as a "key proposition" in the domain of online education.

\section{Preliminary analysis based on evidence}

In general, almost every student indicated that effective online courses do need to enact the "Guide on the Side” pedagogical model. For example, a student stated, “A traditional classroom instructor is more like an unapproachable figure up on the stage every other day. In the online course, the instructor is there to guide students through the course, to actually help them think critically rather than just spit information out." Another student also agreed, noting that "The instructor is more of a guide in the online learning experience while traditionally the instructor is the... vessel of knowledge.” Yet another pointed out that “... because in a classroom atmosphere the instructor is basically on stage and an online instructor is more of a guide to help you in your courses than an instructor. There is not as much lecturing... as a student, you kind of learn on your own and ask the instructor for help.” One student however indicated that he was interested in learning from a "Subject Matter Expert" and did not care if the expert enacted the role of a guide or a sage in his courses, online or face-to-face.

Among instructors, almost paralleling the discussion on the previous myth, there was a clear opinion split regarding the desirability of changing to a "guide on the side" in an online setting from the (apparently) more familiar "sage on the stage" mode. Examples of quotations that reflect rejection of the idea behind this myth include "In the discussions I have had with [online educational specialists], they would say, 'Well, we don't want to be the sage on the stage, we want to be guide on the side.' I think that is an assumption among the educational community... I think the educational community is by and large in the grip of weird educational philosophy." A somewhat cynical point of view was expressed by another instructor, who stated that "Unfortunately many online professors tend to design online courses so that students can more or less self-teach themselves," almost suggesting a dereliction of duty. Yet others agreed with the fact that online courses needed a "guide on the side" approach rather than a "sage on the stage" approach. For instance, one instructor stated, "That's what I have discovered to be true, ok... In the online environment, it is more a mentoring thing and [you are] more of a guide..."

Our own conclusion is that the "guide" versus "sage" debate reflects deep-rooted assumptions and philosophical beliefs regarding the nature of education, including online education, rather than empirical reality associating pedagogical style and effectiveness of courses delivered over different media. In fact, we would go further and question the validity of the deterministic argument of a "guide on the side" approach universally leading to a more effective online learning experience than a "sage on the stage" approach. We contend that the decision to act as a guide or sage depends on a host of contextual issues including the nature of knowledge involved and the nature of the audience, and certainly not by the medium (FTF versus online) alone as implied in the myth.

\section{MYTH \#4: Any IS faculty can teach online, any IS student can learn online, and any IS course can be taught online.}

This myth starts with the belief that professors will be eager to participate in an online venture, and that being successful in this environment does not require any traits or skills that are different from teaching a traditional course. An additional notion is that the web is an appropriate medium for any type of course. This part of the myth views the web as a medium that enables the delivery 
of courses that were created within another framework (Carr-Chellman \& Duchastel, 2001), and that all a professor needs to do is to make a few changes to his/her traditional course to prepare it for the online environment. In many cases, entire degree programs are being offered online, which inherently implies that any course can successfully be taught online. Online education is also seen as the remedy for the large masses of the population who for some reason or another cannot attend a traditional university. In fact, it has been stated that if technology continues its rapid growth, the need for students to be physically present in the classroom will be eliminated (Charp, 2000). This bold statement makes the assumption that the online learning environment is appropriate for everyone and that there are no technological, motivational, or cognitive/intellective skill barriers that would prohibit entry into, or successful completion of, an online course or program.

\section{Preliminary analysis based on evidence}

An examination of the points of view of both students and instructors suggests that this myth may not be tenable. For example, instructors as well as students stressed the need for "personal discipline," "literacy," and "motivation" in order for a student to be successful in the online environment. This same sentiment was echoed by other researchers examining web-based education when they stated that students must be mature, responsible, motivated, and computer literate (Aggarwal \& Bento, 2000; Hiltz, 1993). The observation by an instructor that "Online classes have a bi-modal distribution" (and not normal distribution as in a comparable FTF class) with a large number of students performing very poorly, further supports the view that a substantial proportion of individuals find it difficult to learn online.

Similarly, both instructors and students indicated that certain kinds of courses and course material are more (or less) suitable for online delivery. While instructors were more tentative in their views as evident in the following quotations (e.g., "I don't know that every course can be taught online," or "Programming courses, I think, are hard to teach online”), students seemed to have a far more definitive view. This is reflected in their statements such as "I personally find it difficult to learn math, programming, and high-logic-based courses this way. What I find easiest is writing or critical thinking style classes," or "A lot of science-based courses should not be taught online," or "Certainly courses involving easier concepts and less instruction, such as English or humanities courses, are easier on an online environment than programming or database courses."

Finally, students seemed unanimous in asserting that all faculty members would not be suitable for courses being delivered online. According to many students, it definitely takes "someone dedicated to helping people learn to teach an online class." One student added, "Some people [faculty-members] do not have the temperament for technology and online communication. Some teachers would definitely find the experience more enjoyable while others would hate it." Along these same lines, web-based education researchers (e.g., Aggarwal \& Bento 2000) note that every faculty member will not know how to help students get the most from this type of environment and thus need pedagogical and technical training to effectively develop and deliver course content.

To summarize, we are not convinced that any aspect of the myth (related to courses, faculty members, or students) holds true. It is clear that students and faculty need to possess certain characteristics. Also, it appears that behavioral and management-oriented courses in IS lend themselves to the online mode much better than courses involving the development of technical skills, at least given the current state-of-the-art in online courseware. 


\section{MYTH \#5: IS Faculty-members receive the same support and re- wards for teaching an online course as they do for teaching a traditional course.}

The fate of a faculty member's success in the online education domain relies to some degree on administrative decisions in academic institutions, even though these decisions may be made by people who have no expertise in computer-mediated pedagogy, scholarship, or general computer operation (Shedletsky \& Aitken, 2001).

Myth \#5 is based on the belief that administrators are aware of the time and effort that goes into converting a traditional course into an online course and are prepared to offer the resource support that may be required when designing and teaching an online course (Markel, 1999). It also presumes that course-load policies will be adjusted in recognition of the fact that an instructor teaching an online course spends appreciably more time communicating with students individually (Markel, 1999), thus making faculty workload significantly higher. In addition, the myth implies that many faculty-members who are embarking on an online endeavor may be under the impression that they will retain the intellectual property rights to the courses they have created. They may also believe that they will be rewarded the same for teaching an online course as they will be for teaching a traditional course when it comes to issues such as tenure and promotion (Markel, 1999).

\section{Preliminary analysis based on evidence}

While most students did not have a good understanding of the issues related to the support and rewards to online course faculty, and therefore did not offer specific opinions, faculty members interviewed generally painted a dismal picture. For example, one instructor stated that his workload for online courses "is proportional to the number of students [and] interactions take a lot of time... "In his view, administration "undervalued" online education. Another instructor stated that administration felt that once the course was developed there was virtually no time requirement, which, in the opinion of this individual, was not an accurate assessment. Prior research on this topic supports this statement and notes that there is a substantial increase in time and energy of online instructors who are perceived to be constantly "on duty" (Hiltz, 1993), and that their "cyber hours" often far exceed the time they would normally have spent in a traditional class with office hours (Aggarwal \& Bento, 2000).

Given that the particular IS online initiative we investigated was relatively new, clear patterns of administration's support and policies regarding the allocation of organizational rewards to online course instructors as compared to traditional FTF course instructors had not become very evident. However, instructors seemed to sense a second tier status associated with teaching the online courses, and were thus willing to continue teaching online courses only as a supplement to their "regular" duties of teaching FTF classes, thereby raising doubts regarding the validity of the myth.

\section{MYTH \#6: Online IS courses provide Just-in-time (JIT) learning.}

Primarily used in logistics, the concept of just-in-time processes originated from increasingly rapid modes of transportation and communication. The concept behind the idea was that items would arrive precisely at the time they were required for use or dispatch. Thus, in a learning context, this metaphor is used to describe the flexibility of online education. Just-in-time learning implies that the information can be communicated to students when and where they need it. In other words, students have access to the right information at the right time (Carr-Chellman \& Duchastel, 2001). In the traditional classroom, most instruction content quickly becomes "inert," as it has little relevance to the life experiences of the learners (Gagne, Yekovich \& Yekovich, 
1993). However, it is believed that through the concept of "just-in-time" learning, which is made possible via the Internet, learners can "download” their own knowledge as per their immediate requirements. The learner-objective environment promoted by the Internet offers learning-ondemand opportunities (Zhang \& Nunamaker, 2003) and makes learning resources and instructional activities available to the learner anywhere and at anytime, thus allowing them to create links and search for knowledge that can interact with their own prior experiences (Carr-Chellman \& Duchastel, 2001; Liaw \& Huang, 2000; Shedletsky \& Aitken, 2001).

\section{Preliminary analysis based on evidence}

Most students seemed to agree with the idea that online education provided an opportunity for JIT learning. For example, a student wrote "Yes, I feel that Just-in-Time Learning explains the online learning experience, given that most of the students enrolled in the program would not be able to fulfill such requirements for their degree without the opportunity to participate when and where their schedule permits." However, one student did comment that the JIT label "sounds like it is trivializing online learning."

Faculty members seemed a lot more divided on this issue. For example, an instructor involved in teaching Visual Basic said, "If I am coding VB, and I need to make a certain type of call to read a database, then I go to [a resource] and look it over. Then I feel I have had JIT learning." Another instructor questioned whether courses structured into 8-week modules being offered during certain semesters could actually be accurately described using the JIT label. In his words, "JIT learning that takes 8 weeks? As part of a series of courses that has prerequisites... I don't think I can call it JIT learning.” He added, "If I am farmer... and if my harvesting goes through October and my planting season starts in March, I need learning over Christmas break. We [the university] don't offer that...” Finally, an instructor, like one of the students (quoted above), expressed his misgivings about the JIT label, since it tended to trivialize the learning process: "I don't like the term 'just-in-time' learning. However, learning that is at the disposal, or available at the time I need it... I think that is where we need to be today... 'Just-in-time' to me seems like it is so casual... I will get it when I need it!”

Our conclusion is that online education may be seen as JIT in the (superficial) sense that it can offer individualized content based on a student's need at the time a student wishes to use the content. However, the symbolism of JIT does break down given the fact that most university-level IS courses have to be taken at a certain time of the year and last for a specific duration.

\section{MYTH \#7: Universities rushing to offer online courses in IS are seen as "digital diploma mills."}

Robert Reid, in his 1959 study of diploma mills for the American Council on Education, described the typical diploma mill as having no classrooms and faculty that are often untrained or nonexistent (Noble, 1998). Thus, the term “digital diploma mill,” coined by David F. Noble, a professor at York University in Toronto, refers to the automation of higher education in which most teaching is done by machine, not faculty, and in which there are no classrooms. This term conjures up a picture of an institution churning out commercialized, computer-based education created by faculty members who may or may not be involved in the dissemination of the courseware over the Internet. The rapid growth of online IS programs being offered by universities in response to high demand for IS courses, faculty shortage, and economic pressures are leading to concerns that universities will be perceived as digital diploma mills. 


\section{Preliminary analysis based on evidence}

While a majority of students agreed that there were a number of diploma mills "out there," they were insistent that their own experiences as students of the online IS program at the university should not be equated as those offered by these mills. Examples abound:

“[Diploma Mills hold] a negative connotation, describing a non-qualified, non-accredited institution giving you a degree with little or no work. To me that isn't what [how] I would describe my experiences...”

"They just take the students money and basically give them a diploma without the student really learning anything. I would not think of $[<$ his university $>$ DDP (Distance Degree Programs in the particular student's university )] in this manner at all.”

“The first thing that comes to my mind are those 'spam' academic diploma mills that tend to fill my e-mail from time to time. There are several well recognized academic institutions that unfortunately have taken advantage of this phenomenon...”

"I have been offered diplomas for free [no work]... I wouldn’t say there are not any diploma mill schools. But the [<university $>$ ] is not one of them. I have been to school a long time and have only taken my last year at the [<university $>$ ] DDP. The classes through DDP are no less rewarding than traditional classes in $[<$ a slightly lower reputation but good regional university>].”

Not surprisingly, student respondents seemed very touchy about the label of "diploma mills." While they acknowledged the existence of diploma mills, they were very careful to distance their own institution from such mills. However, one student, with a particularly positive orientation toward online education, argued that the label of "diploma mills" was unfair, since it implied that "the diplomas are just processed to generate more income... [w] hen in reality they [such institutions] are providing higher education to millions of families, which without such an opportunity, would merely settle for mediocrity."

Faculty members' remarks reflected two main themes: first, similar to the view expressed by many students, there was an acknowledgment of the existence of diploma mills and the potentially cheapening effect of these mills on academics; and second, there was a questioning of why a "digital diploma needs to be any less," and a contention that "many traditional professors and academicians are threatened by online education, so they will try and discount that [online education] by using those phrases."

Our conclusion here is that students as well as faculty reject the idea that universities offering online IS courses automatically become digital diploma mills, where the label has the negative connotation of poor quality educational experience for masses. (Of course, for a more reliable evaluation of the issue, the views of other stakeholders of the courses (e.g., potential employers) also need to be taken into consideration.) In addition, a somewhat unexpected finding was that a number of professors, and even one student, appear to be questioning why the term "digital diploma mill” should be viewed as negative in the first place.

It is our view, that over time, the term will lose its negative stigma, and will simply refer to the fact that a highly automated and integrated business process routinely issues diplomas to those who complete online course requirements.

\section{Conclusion and Implications}

For fear of being left behind, many universities are plunging into the online education waters without much reflection (Rudestam \& Schoenholtz-Read, 2002). Administrators of these institutions seem to think "everyone else is doing it, so there must be something to it" - in other words, 
they see this transition as a necessity in this age of hyper-competition. Within this broader context facing higher education, most disciplinary areas in universities, including information systems (IS) departments, are willingly, though sometimes blindly, jumping on the bandwagon by converting their traditionally taught courses into online courses. Their efforts are often guided by the myths floating around in the discourse on the topic. Given the potentially serious ramifications of IS academics unreflectively enacting the myths related to online education, we have argued for the need to critically examine the so-called truths being authoritatively set forth in much of the literature.

The results of our preliminary examination of seven key myths on this topic may be summarized as follows:

- Myth \#1 (i.e., Technological connectivity implies interaction among participants in online IS courses), and Myth \# 4 (i.e., Any IS faculty can teach online, any IS student can learn online, and any IS course can be taught online) appear to be fundamentally false.

- Myths \#2 (i.e., For online IS courses to be effective, they should embody a studentcentered learning philosophy) and Myth \#6 (i.e., Online IS courses provide Just-in-time (JIT) learning) are ambiguous because the notions of "JIT" and "student-centeredness" are not sufficiently clear.

- The evidence regarding Myth \#5, related to the degree of support and rewards associated with online course teaching, and Myth \# 7, related to universities being viewed as digital diploma mills as a result of offering online IS courses, while very limited, seems to suggest that the myths are not valid and need to be carefully re-examined.

- Finally, Myth \#3, dealing with the relative efficacy of the "Sage on the Stage" and the "Guide on the Side" cannot be validated or falsified meaningfully, since the points of view of course expressed by participants (i.e., students and instructors) reflect their deeprooted assumptions that are difficult to separate from their actual experiences.

We conclude the paper with a reminder that our study is exploratory and thus the findings are not to be viewed as a definitive validation or falsification of the myths identified; rather, our goal is to sensitize the entire academic community, based on some evidence surrounding an online IS undergraduate degree program, about some of the implicit (and perhaps questionable) assumptions that may be pervading our thought processes regarding online courses. Through this paper, we hope to initiate a conversation in the academic community so that online faculty-members can be more informed about key issues associated with designing and offering courses in an ICTmediated environment.

While we see our work as a valuable first step, clearly much remains to be explored in this nascent though vital arena. Though it may not be feasible to empirically examine each of the myths discussed in this paper, future IS research can certainly test the validity of several of these myths by focusing on issues of interactivity, course design and delivery, the skills and characteristics required by both students and faculty to be successful in an online domain, as well as examining administrative beliefs about online education. There also exist a number of topics that did not appear as recurring myths in the online education literature but are still in need of further investigation, such as learning assessment, learning outcomes, group work, instructor workload requirements, and long-term student benefits.

\section{References}

Abraham, T. (2002). Evaluating the virtual management information systems classroom. Journal of Information Systems Education, 13 (2), 125. 
Aggarwal, A.K. (2003). Internalization of end-users. Journal of Organizational and End User Computing, 15 (1), 54.

Aggarwal, A., \& Bento, R. (2000). Web-based education. In A. Aggarwal (Ed.), Web-based learning and teaching technologies: Opportunities and challenges. Hershey, PA: Idea Group.

Argyris, C., \& Schön, D. A. (1978). Organizational learning: A theory of action perspective. Reading, MA: Addison-Wesley.

Belanger, F., \& Jordan, D. H. (2000). Evaluation and implementation of distance learning: Technologies, tools, and techniques. Hershey, PA: Idea Group.

Benbunan-Fich, R., \& Hiltz, S. R. (2003). Mediators of the effectiveness of online courses. IEEE Transactions on Professional Communication, 46(4), 298-312.

Bernard, R.M., Rojo de Rubalcava, B., \& St.Pierre, D. (2000). Collaborative online distance learning: Issues for future practice and research. Distance Education, 21 (2), 260-277.

Bolman, L. \& Deal, T. (1984). Modern approaches to understanding and managing organizations. San Francisco, CA: Jossey-Bass.

Carr-Chellman, A., \& Duchastel, P. (2001). The ideal online course. Library Trends, 50 (1), 145-158.

Charp, S. (2000). Distance education. T.H.E. Journal, 27 (9), 10-12.

Clarke, B.L. (1998, Fall). Getting a degree via your PC. Money Magazine, 1 (2), 66-69.

Cleary, S. (2001, March 12). The downside: Why some critics give web-based education less than stellar grades [Special report]. The Wall Street Journal, pp. R32.

Cohen, P. (1969). Theories of myth. Man, 4, 337-353.

Coppola, N.W., Hiltz, S.R., \& Rotter, N.G. (2002). Becoming a virtual professor: Pedagogical roles and asynchronous learning networks. Journal of Management Information Systems, 18 (4), 169-189.

Davenport, T. H., \& Stoddard, D. B. (1994). Reengineering: Business change of mythic proportions? MIS Quarterly, 18 (2), 121-127.

Dewey, J. (1938). Experience and education. New York: Collier Macmillan.

Dufner, D., Kwon, O., \& Hadidi, R. (1999). Web-CCAT: A collaborative learning environment. Communications of the AIS, 1.

Eastmond, D.V. (1996). Computer-mediated communications. International Encyclopedia of Educational Technology ( $2^{\text {nd }}$ ed.), 382-389.

Frost, P.J., \& Morgan, G. (1983). Symbols and sensemaking: The real-ization of a framework. In L. R. Pondy, P. J. Frost, G. Morgan, \& T. C. Dandridge, Organizational symbolism. Greenwich, CT: JAI Press.

Gagne, E., Yekovich, C.W., \& Yekovich, F. (1993). The cognitive psychology of school learning (2 ${ }^{\text {nd }}$ ed). New York: HarperCollins.

Hamilton, D. P. (2001, March 12). No substitute: The Internet does not change everything [Special report]. The Wall Street Journal, pp. R32.

Hiltz, S.R. (1993). The virtual classroom: Learning without limits via computer networks. Norwood, New Jersey: Ablex Publishing.

Hiltz, S.R. (1995). Teaching in a virtual classroom. International Journal of Educational Telecommunications, 1 (2), 185-198.

Hiltz, S.R., \& Turoff, M. (2002). What makes learning networks effective? Communications of the ACM, 45 (4).

Hirschheim, R., \& Newman, M. (1991). Symbolism and information systems development: Myth, metaphor and magic. Information Systems Research, 2, 29-62. 
Hot Business Opportunity: e-learning. (January 26, 2005). Retrieved March 30, 2005, from http://onlinebusiness.about.com/b/a/2005_01_26.htm.

Huynh, M.Q., Umesh, U.N., \& Valacich, J.S. (2003). E-Learning as an emerging entrepreneurial enterprise in universities and firms. Communications of the AIS, 12, 48-66.

Kaarst-Brown, M.L., \& Robey, D. (1999). More on myth, magic, and metaphor: Cultural insights into the management of information technology in organizations. Information Technology \& People, 12 (2), 192-217.

Kasworm, C., Sandmann, L. R., \& Sissel, P. A. (2000). Adult learners in higher education. In A. L. Wilson \& E. R. Hayes (Eds.), Handbook of adult and continuing education (pp. 449-463). San Francisco, CA: Jossey-Bass.

Lee, A. S. (1991). Integrating positivist and interpretivist approaches to organizational research. Organization Science 2 (4), 342-365.

Leidner, D. E., \& Jarvenpaa, S. L. (1995). The use of information technology to enhance management school education: A theoretical view. MIS Quarterly, 19 (3), 265-291.

Lenzer, R., \& Johnson, S. S. (1997, March 10). Seeing things as they really are. Forbes, 122-128.

Liaw, S., \& Huang, H. (2000). Enhancing interactivity in web-based instruction: A review of the literature. Educational Technology, 30 (3), 41-45.

Lu, J., Yu, C., \& Liu, C. (2003). Learning style, learning patterns, and learning performance in a WebCTbased MIS course. Information and Management, 40, 497-507.

Markel, M. (1999). Distance education and the myth of the new pedagogy. Journal of Business and Technical Communication, 13 (2), 208-222.

Markus, M. L., \& Robey, D. (1988). Information technology and organizational change: Causal structure in theory and research. Management Science, 34, pp. 583-598.

Molenda, M., \& Harris, P. (2001). Issues and trends in instructional technology. Educational Media and Technology Yearbook, 26, 3-15.

Moore, C. (2001). E-learning leaps into the limelight. Retrieved April 12, 2002, from http://www.cnn.com/2001/TECH/internet/12/11/elearning.leaps.idg/index.html

Morgan, G. (1983). Beyond method. Beverly Hills, CA: Sage Publications.

Morrissey, C. A. (2002). Rethinking the virtual university. Communications of the AIS, 9, 456-466.

Murphy, K. L., \& Cifuentes, L. (2001). Using web tools, collaborating, and learning online. Distance Education, 22 (2), 285-305.

Neumann, P.G. (1998). Risks of E-education. Communications of the ACM, 41(10), 136.

Noble, D. F. (1998). Digital diploma mills: The automation of higher education. Retrieved on March 19, 2003 from http://firstmonday.org/issues/issue3_1/noble/index.html

Orlikowski, W. J., \& Baroudi, J. J. (1991). Studying information technology in organizations: Research approaches and assumptions. Information Systems Research, 2 (1), 1-28.

Piccoli, G., Ahmad, R., \& Ives, B. (2001). Web-based virtual learning environments: A research framework and preliminary assessment of effectiveness in basic IT skills training. MIS Quarterly, 25(4), 401-426.

Polkinghorne, D. E. (1988). Narrative knowing and the human sciences. Albany, NY: State University of New York Press.

Raymond III, F. B. (2000). Delivering distance education through technology: A pioneer's experience. Campus-Wide Information Systems, 17 (2), 49-57.

Reiser, R.A. (1987). Instructional Technology: A History. In R.M. Gagne (Ed.), Instructional Technology: Foundations (pp. 11-48). Hillsdale, NJ: Lawrence Erlbaum. 
Rudestam, K. E., \& Schoenholtz-Read, J. (2002). Handbook of online learning: Innovations in higher education and corporate training. Thousand Oaks, CA: Sage.

Sarker, S., \& Lee, A. S. (2002). Using a positivist case research methodology to test three competing practitioner theories-in-use of business process redesign. Journal of the AIS, 2 (7), 1-72.

Schank, R. C. (2001). Revolutionizing the traditional classroom course. Communications of the ACM, 44 (12).

Schultze, U., \& Orlikowski, W. J. (2001). Metaphors of virtuality: Shaping an emergent reality. Information and Organization, 11, 45-77.

Schrum, L. (1999). Trends in distance learning: Lessons to inform practice. Educational Media and Technology Yearbook, 24, 11-16.

Shaw, G.C. (2000). Debunking the myth of academe. Thought \& Action, 16 (2), 29-40.

Shedletsky, L. J., \& Aitken, J. E. (2001). The paradoxes of online academic work. Communication Education, 50 (3), 206-217.

Smircich, L. (1983). Organizations as shared meanings. In L. R. Pondy, P. J. Frost, G. Morgan, \& T. C. Dandridge, Organizational symbolism. Greenwich, CT: JAI Press.

Trice, H. M., \& Beyer, J. M. (1984). Studying organizational cultures through rites and ceremonies. Academy of Management Review, 9, 653-669.

The virtual classroom versus the real one. (2000). Retrieved on April 12, 2002, from http://www.forbes.com/global/2000/0918/0318114a_print.html

Vygotsky, L. S. (1978). Mind in society: The development of higher psychological processes. Cambridge, MA: Harvard University Press.

Watson-Manheim, M.B., Crowston, K., \& Chudoba, K.M. (2002). A new perspective on "virtual”: Analyzing discontinuities in the work environment. Proceedings of the $35^{\text {th }}$ Hawaii International Conference on System Sciences.

Weber, T. E. (2000, July 28). Allen is Wooing Elite Colleges to Teach Online. The Wall Street Journal, p. B1.

Weisenberg, F., \& Hutton, S. (1996). Teaching a graduate program using computer-mediated conferencing software. Journal of Distance Education, 11, 83-100.

Yellen, R. E. (2000). Reaching the future information systems worker with distant learning. Journal of Organizational and End User Computing, 12 (4), 29.

Zang, D., \& Nunamaker, J. F. (2003). Powering e-learning in the new millennium: An overview of elearning and enabling technology. Information Systems Frontiers, 5 (2), 207.

\section{Biographies}

Suprateek Sarker is an Associate Professor of Information Systems at Washington State University. He has also recently served as a Visiting Professor at Copenhagen Business School, Denmark, Helsinki School of Economics, Finland, National Economics University, Vietnam, and Cesar-Ritz University Center, Switzerland. His research focuses on the use of qualitative method-

ologies to study phenomena such as BPR/ERP implementation, global virtual teamwork, and MCommerce.

Jennifer Nicholson is a Management Information Systems Ph.D. candidate at Washington State University. Her research interests include investigating the impacts and potential benefits of computer-mediated learning in both an organizational and higher education context. She has published papers in the ICIER, AMCIS, and HICSS conference proceedings.

Note: Both authors contributed equally to this paper. 